\title{
ESTUDO DO MÉTODO DE EMPILHAMENTO SRC E APLICAÇÃO EM DADOS SINTÉTICOS E REAIS
}

\author{
Waldomiro Gomes Paschoal Junior \\ Orientador: Dr. German Garabito Callapino (UFPA) \\ 103 p. - Dissertação (Mestrado) - Defesa 12.05.2005
}

\begin{abstract}
RESUMO. 0 empilhamento sísmico é um método de imageamento utilizado para simulação de seções sísmicas com afastamento nulo (AN) a partir de dados de cobertura múltipla, produzindo um aumento da razão sinal/ruído na seção simulada. Este método é realizado usando o processamento convencional denominado ponto médio comum (PMC), através das chamadas correções sobretempo normal e sobretempo oblíquo (STN/STO). Alternativamente, um novo método de empilhamento sísmico, denominado superfície de reflexão comum (SRC) pode ser usado para simular seções sísmicas em afastamento nulo (AN). 0 método SRC tem como principais características: 1) a construção de uma aproximação do tempo de trânsito de reflexões primárias na vizinhança de um raio de reflexão normal; 2) esta aproximação de empilhamento tem como parâmetros os ângulos de emergência do raio normal e os raios de curvaturas de duas ondas hipotéticas denominadas onda ponto de incidência normal (onda PIN) e onda normal (onda N). 0 método pressupõe ainda que a velocidade da onda longitudinal na parte superior do modelo próxima à superfície da Terra seja conhecida. Para determinar adequadamente os parâmetros supracitados, fundamentais para o método de imageamento SRC, são necessárias estratégias de busca que utilizem casos particulares da aproximação de segunda ordem hiperbólica dos tempos de trânsito. As estratégias de busca apresentadas são: SRC pragmático-extendito e SRC global-local. Neste trabalho é apresentada uma revisão extensa dos fundamentos teóricos de método de empilhamento SRC, como também das estratégias de busca dos parâmetros SRC, dos algoritmos de implementação, e da delimitação de aberturas do operador de empilhamento SRC usando conceitos de zonas de Fresnel e o fator de estiramento da correção STN. Como um exemplo de aplicação dos atributos ou parâmetros SRC é apresentado o resultado da correção STN, sem estiramento do sinal sísmico, obtido utilizando as velocidades estimadas dos parâmetros SRC. Também, são apresentados os resultados da aplicação dos três métodos de empilhamento (PMC (STN/STO), SRC pragmático-extendido, SRC global-local) nos dados sintéticos Marmousi e real terrestre da bacia paleozóica Amazônica. Finalmente apresentam-se as discussões sobre os resultados, quanto à resolução da imagem sísmica e custo computacional.
\end{abstract}

ABSTRACT. Seismic stacking is a method designed to simulate zero-offset (ZO) seismic sections from multi-coverage seismic data. The resulting simulated ZO section gives rise to a significant increase of the signal to noise ratio. This method is done by means of seismic processing socalled the common mid point (CMP) method, through makes use of the so-called normal moveout and dip moveout (NMO/DMO) corrections. In this work, a new seismic stacking method called common reflection surface (CRS) is used to simulate ZO seismic sections. The main characteristic of the CRS method is: 1) the use of a more general, multi-parametric stacking operator that approximates the traveltimes of the primary reflections for sources and receiver pairs arbitrarily located on the vicinity of the normal ray. The parameters or attributes of the stacking operator are the radii of curvatures of two hypothetical waves called normal incidence point (NIP) wave and normal (N) wave; as well as the emergency angle of the normal ray. The CRS method assumes that the near-surface velocity is a priori known. To determine the abovementioned parameters appropriately, main for the CRS imaging method, is necessary search strategies that use cases special of the approach of second hyperbolic order of the traveltimes. The presented search strategies are: extended-pragmatic CRS and global-Iocal CRS. To show the efficiency of these strategies they are applied in the synthetic Marmousi and real land datasets of the Amazon palaeozoic basin. As result sections Z0 simulated by three different stacking methods (CMP, CRS extendedpragmatic and global-local CRS), to compare the efficiency of these, with relationship I cost her computational and the resolution of the seismic image. 